\title{
JGZ-Richtlijn ‘Huidafwijkingen’
}

\section{Doel van de richtlijn}

Het doel van deze richtlijn is het tijdig signaleren, bege leiden en verwijzen van kinderen met huidafwijkingen en hun ouders door de jeugdgezondheidszorg (JGZ).

\section{Waarom deze richtlijn?}

Huidafwijkingen komen vaak voor, ook bij kinderen. Huidafwijkingen staan met een incidentie van 287 per 1000 kinderen per jaar boven aan de lijst van meest voorkomende diagnosen die de huisarts bij kinderen stelt. Sommige huidafwijkingen ontstaan door een (onderliggende) ziekte, een syndroom of kindermishandeling. Het is daarom van groot belang deze huidafwijkingen met mogelijk onderliggende oorzaken vroegtijdig te signaleren. Huidafwijkingen kunnen een grote psychosociale impact hebben, bijvoorbeeld omdat het kind last van jeuk heeft of omdat het kind vanwege de huidafwijking wordt gepest. Preventie, signalering, diagnose en behandeling van huidafwijkingen, eventueel tijdige verwijzing en uniforme voorlichting en advisering (begeleiding) ten aanzien van huidafwijkingen zijn belangrijk voor het individuele kind en zijn ouders, en voor de maatschappij.

\section{Inhoud van de richtlijn}

De richtlijn bevat algemene informatie op het gebied van preventie (bescherming tegen de zon, droge huid), signalering (actieve opsporing, inspectie en palpatie), diagnostiek (ondersteund door een webbased tool), begeleiding (welzijn van ouder en kind, therapietrouw, angst voor het gebruik van zalf met corticosteroïden, ook bekend als corticofobie), behandeling van huidafwijkingen en verwijzing van het kind bij huidafwijkingen. In de richtlijn wordt specifieke aandacht besteed aan huidafwijkingen bij kinderen met een donkere of getinte huid. Een apart hoofdstuk is gewijd aan de kwaliteit van leven van kinderen met een huidaandoening in het algemeen en aan kinderen met constitutioneel eczeem in het bijzonder.

\section{Webbased tool}

In de webbased tool (http://jgzhuid.plusportservices. com/) zijn de wetenschappelijke evidentie, gegevens uit handboeken en de mening van experts over meer dan 75 huidafwijkingen opgenomen. De website bevat stroom schema's, waarmee op basis van het aspect (zoals vorm en kleur) van de huidaandoening een differentiaaldiagnose geformuleerd kan worden. De stroomschema's gaan uit van de volgende meest opvallende kenmerken, namelijk: een verhevenheid/bultje, een lokale verkleuring of roodheid. Daarnaast is er aandacht voor midline laesies (afwijkingen in de middellijn van het lichaam), nagelafwijkingen en kaalheid. Op de website staat een beschrijving van de huidafwijkingen, ondersteund met afbeeldingen. Tevens wordt advies gegeven over mogelijke acties: expectatief beleid, begeleiding binnen de JGZ of verwijzing.

De website vormt de basis van waaruit de JGZ-medewerker een onderscheid moet kunnen maken tussen een huidafwijking die verwijzing behoeft en een huidafwijking die geen verwijzing behoeft.

\section{Activiteiten}

De JGZ voert onderstaande activiteiten uit:

- Tijdig signaleren en verwijzen bij bepaalde huidafwijkingen, die geassocieerd kunnen zijn met onderliggende problematiek en syndromen.

- Voorlichting geven over huidafwijkingen die onschuldig en zelflimiterend van aard zijn.

- Adviseren over het toepassen van zelfzorgmedicatie.

- Begeleiden bij de behandeling van huidafwijkingen door het geven van uitleg, optimaliseren van behandelen verzorgadviezen, bevorderen van therapietrouw en door het signaleren van psychosociale problemen.

Actieve opsporing van huidafwijkingen Een aantal huidafwijkingen komt in aanmerking voor actieve opsporing in de JGZ, omdat vroegsignalering een ernstiger afwijking of ernstiger lijden kan voorkomen. Op grond van bestaande richtlijnen, literatuur en afstemming met ketenpartners (jeugdarts, verloskundi ge, huisarts, dermatoloog en kinderarts) zijn leeftijden bepaald waarop kinderen op deze huidafwijkingen dienen te worden onderzocht. Er zijn heldere verwijscriteria opgesteld. Het gaat om de volgende huidafwijkingen: congenitale naevi, café-au-laitvlekken, hemangiomen, vaatmalformaties, midline laesies en signalen van kindermishandeling of automutilatie.

\section{Wat levert deze richtlijn op?}

Voor ouders en kind

Door tijdig signaleren en verwijzen kunnen bepaalde aandoeningen eerder ontdekt en zo nodig behandeld worden, waardoor complicaties worden voorkomen, zoals een bedreigd oog door een hemangioom. Begelei- 
ding kan leiden tot betere therapietrouw, waardoor het kind minder klachten heeft (bijvoorbeeld minder jeuk bij eczeem) en de huidafwijking minder invloed heeft, zowel op de korte als op de lange termijn (bijvoorbeeld slaapproblemen respectievelijk littekens door krabben). De JGZ heeft ook aandacht voor de mogelijke psychosociale problemen ten gevolge van huidafwijkingen en verwijst, indien nodig, tijdig door (bijvoorbeeld bij pesten vanwege eczeem). Voorlichting en advies over huidverzorging en -afwijkingen kunnen onzekerheden wegnemen, daarnaast kan het inzetten van behandeling een contact met de huisarts/specialist voorkomen. Door preventieve adviezen over zonbescherming wordt zonverbranding voorkomen, wat bijdraagt aan de preventie van huidkanker. Begeleiding door de JGZ is laagdrempelig en voor ouders gratis (geen eigen risico).

\section{Voor de maatschappij}

De JGZ voorkomt medische kosten wanneer zij de begeleiding op zich neernt, bijvoorbeeld omdat er minder vaak doorverwijzing nodig is naar eerste en tweede lijn of doordat complicaties van de huidafwijking worden voorkomen. Tevens voorkomt de JGZ hogere kosten voor gemeenten omdat psychosociale problemen ten gevolge van bepaalde huidafwijkingen worden voorkomen.

Wat vinden jeugdzorgprofessionals?

Jolanda Rutten, verpleegkundig specialist preventie bij
Zorggroep Almere, is lid geweest van de kernredactie van de richtlijn. Zij beschrijft haar ervaringen met het werken met de richtlijn als volgt: “De richtlijn geeft in de dagelijkse praktijk duidelijke handvatten voor het adviseren van ouders en contacten met ketenpartners. De richtlijn draagt bij aan uniforme advisering, wat de kwaliteit van zorg ten goede komt. De webbased tool is een goed bruikbaar instrument, het kost echter wel extra tijd, vooral als de computer niet al te snel werkt. Ik gebruik de webbased tool sorns ter ondersteuning van mijn voorlichting aan ouders. Zo kon ik de moeder van een meisje met baby-acne aan de hand van de plaatjes laten zien wat het was; dit stelde moeder gerust. Tevens heb ik bij een kind met een donkere huid aan de hand van de richtlijn contact gehad met een huisarts. Ik heb het advies uit de richtlijn om een andere zalf te gebruiken besproken. Naar aanleiding van dit overleg heeft de huisarts het beleid aangepast. Met succes, zo bleek na enige tijd!"

Waar kunt u deze richtlijn vinden?

De richtlijn met toebehoren is beschikbaar via www.ncj.nl. Via www.jgzacademie.nl is een e-learningmodule beschikbaar.

Financiële ondersteuning: ZonMw.

\section{JGZ-Richtlijn 'Zindelijkheid urine en feces'}

\section{Doel van de richtlijn}

Het doel van de richtlijn is het voorkomen van zindelijkheidsproblemen en het tijdig signaleren en begeleiden of verwijzen van ouders en hun kinderen met dergelijke problemen door de jeugdgezondheidszorg (JGZ). Een tweede doel is het geven van voorlichting aan scholen en kinderopvang over onzindelijkheid.

\section{Waarom deze richtlijn?}

Problemen met zindelijkheid komen veel voor op de kinderleeftijd en kunnen een grote impact hebben. Bedplassen komt voor bij ongeveer $15 \%$ van de 5 -jarigen, broekplassen bij ongeveer $7 \%$ van de 4 - tot 7 -jarigen en fecale incontinentie bij 1-4\% van de kinderen vanaf 4 jaar. Zindelijkheidsproblemen komen vaker voor bij jongens en bij kinderen van Turkse en Marokkaanse afkomst. Van de adolescenten is nog 1 op de 50 onzindelijk 's nachts voor urine en van de volwassenen s op de 200.

Diverse studies tonen aan dat kinderen sneller zindelijk worden door begeleiding en behandeling dan wanneer wordt afgewacht. Het voorkómen en zo nodig behandelen van obstipatie is essentieel bij de preventie van fecale incontinentie. Het is daarom belangrijk zindelijkheidsproblemen vroegtijdig te signaleren en de effectiefste interventie toe te passen. De JGZ is bij uitstek de instantie die daarvoor kan zorgen. 